\title{
Growth Hormone Stimulates Bone Healing in a Critical-sized Bone Defect Model
}

\author{
L. F. H. Theyse, DVM*; M. A. Oosterlaken-Dijksterhuis, PhD*; J. van Doorn, PhD†; \\ W. J. A. Dhert, PhD\$; and H. A. W. Hazewinkel, PhD*
}

\begin{abstract}
Growth hormone plays an important role in bone metabolism. Treating bone deficits is a major topic in orthopaedic surgery. Our hypothesis was that local continuous growth hormone administration stimulates bone healing in a canine critical-sized bone defect model. Bone formation in the defects was quantified using densitometric image analysis and histomorphometry. After growth hormone treatment, expression levels of insulin-like growth factors-I and II, and growth hormone receptor were determined in the bone regenerate of the original defects. Circulating plasma concentrations of insulin-like growth factors-I and II, and insulinlike growth factor binding proteins-4, and 6 were measured during treatment. Growth hormone administration resulted in healing of bone defects but without an additional effect of local infusion. Expression of insulin-like growth factor-I in the bone regenerate was lower in the growth hormonetreated dogs, whereas insulin-like growth factor-II and growth hormone receptor expression were not increased. Growth hormone increased circulating insulin-like growth factor-I and growth factor-II plasma concentrations. Continuous infusion of growth hormone stimulated bone healing in a canine critical-sized bone defect model. Local delivery of growth hormone did not additionally enhance bone healing. Increased circulating plasma concentrations of insulin-like growth factors-I and II most likely induced bone formation.
\end{abstract}

Received: April 29, 2005

Revised: September 16, 2005

Accepted: November 16, 2005

From the *Department of Clinical Sciences of Companion Animals, Faculty of Veterinary Medicine; †Laboratory of Endocrine and Metabolic Diseases, Wilhelmina Children's Hospital; and the §Department of Orthopedics, University Medical Centre; Utrecht University, Utrecht, The Netherlands.

Each author certifies that he or she has no commercial associations (eg, consultancies, stock ownership, equity interest, patent/licensing arrangements, etc.) that might pose a conflict of interest in connection with the submitted article.

Each author certifies that his or her institution has approved the animal protocol for this investigation and that all investigations were conducted in conformity with ethical principles of research.

Correspondence to: L. F. H. Theyse, DVM, DECVS. Department of Clinical Sciences of Companion Animals, Faculty of Veterinary Medicine, Utrecht University, P.O. Box 80.154, NL-3508 TD Utrecht, The Netherlands. Phone: 0031-302539411; Fax: 0031-302518126; E-mail: L.F.H.Theyse@vet.uu.nl. DOI: 10.1097/01.blo.0000203490.21206.7f
Bone healing is mediated through complex interactions of growth factors, hormones, cytokines, and matrixassociated proteins. Bone is under endocrine control by several hormones, including growth hormone, parathyroid hormone, calcitonin, estrogens, and androgens. ${ }^{6,14-16,40}$ Growth hormone $(\mathrm{GH})$ and insulin-like growth factors-I and II (IGF-I and IGF-II) play a critical role during bone growth and bone accretion. ${ }^{31}$ The actions of IGF-I and IGF-II are modulated through their six high-affinity binding proteins (IGFBPs). ${ }^{26,30}$ In general, IGFBP-1, IGFBP2, IGFBP-4, and IGFBP-6 inhibit and IGFBP-3 and IGFBP -5 stimulate osteoblast function.

Stimulating bone formation, using $\mathrm{GH}$, growth factors, and to a lesser extent cytokines, is of major interest in dealing with compound fractures, bone deficits, and arthrodeses. Various studies have shown the applicability of these factors as osteoinductive agents and as accelerators of bone healing. ${ }^{7,20,29,34,43}$ The actions of $\mathrm{GH}$ on bone are twofold. First, GH exerts a direct stimulatory effect on longitudinal bone growth and on bone healing. ${ }^{6,21}$ Second, GH has an indirect effect, which is supposed to be mediated mainly through induction of IGF-I. ${ }^{6,8,12,14,24,35}$ Systemic application of GH-stimulated bone healing has been shown in several fracture models. ${ }^{9,21,34,44}$ In a porcine distraction osteogenesis model, systemic treatment with GH accelerated bone healing after lengthening. ${ }^{2,3,33} \mathrm{Al}-$ though GH enhanced bone formation in these models, they did not use critical-sized bone defects. As major bone loss and defects are major concerns in orthopaedic surgery, stimulation of bone healing in these cases is critical.

We hypothesized that continuous $\mathrm{GH}$ administration induces bone healing in a canine critical-sized bone defect model. In addition, we hypothesized that GH administration stimulated bone healing by increasing the expression of IGF-I, IGF-II, and GH receptor in the bone regenerate of the original defect. ${ }^{4,11,19,21,27}$

\section{MATERIALS AND METHODS}

Eight mature Labrador retrievers were allocated with an even gender distribution to one treatment $(n=4)$ and one control 
group $(n=4)$. Four dogs were treated with GH and four dogs in the control group received a placebo solution. Sample size was determined assuming a difference between means of $50 \%$ with a common standard deviation for both groups of $20 \%$, a significance level of 0.05 , and a power of 0.80 . The equal sample size for both groups was calculated to be 2.97. Four females and four males were included, with an age of $32 \pm 5$ months (mean \pm SEM), and a body weight of $31 \pm 1 \mathrm{~kg}$ (mean \pm SEM). Bilateral ulnar critical-sized bone defects were created. ${ }^{7}$ A critical-sized bone defect is designed not to heal spontaneously, and therefore, will result in a nonunion. In the four $\mathrm{GH}$-treated dogs, the bone defect in the right ulna was infused continuously with GH using an osmotic pump with a catheter placed inside the defect. In the control group, the defects in the right ulna were infused with placebo solution. The formation of new bone was evaluated, using densitometric image analysis and histomorphometry. To assess bone healing in the defects, bone formation was monitored until 6 weeks after starting GH treatment. Bone healing in the defects was compared between the GH-treated group (eight defects) and the control group (eight defects). In addition, differences in bone healing in the GH-treated dogs between the right-sided and left-sided defects (four each) were determined. Circulating plasma concentrations of GH, IGF-I, IGF-II, IGFBP4, and IGFBP-6 were determined to assess the systemic effect of GH treatment. Only IGFBP-4 and IGFBP-6 were included because determining additional IGF-binding proteins in dog plasma was not yet feasible. After 6 weeks, segmental bone specimens were collected to measure the expression levels of IGF-I, IGF-II, and GH receptor in the original bone defects. Because of the lack of proper sequences of canine IGFBP-4 and IGFBP-6 mRNAs, we were not able to amplify IGFBP mRNA in canine tissue samples. Enhanced bone healing was expected to coincide with increased circulating plasma concentrations of IGF-I and IGF-II and lower concentrations of inhibiting binding

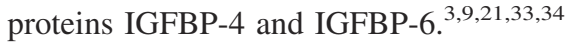

After sedation with medetomidine (Domitor®, Pfizer Animal Health B.V., Capelle a/d IJssel, The Netherlands), anesthesia was induced intravenously with propofol (Rapinovet ${ }$, Schering-Plough Animal Health N.V., Bruxelles, Belgium), and maintained by inhalation anesthesia with isoflurane, nitrous oxide, and oxygen. Amoxicillin with clavulanic acid (Augmentin ${ }^{\circ}$, SmithKline Beecham Farma B.V., Rijswijk, The Netherlands) was administered intravenously ( $20 \mathrm{mg} / \mathrm{kg}$ body weight) before surgery. Both front limbs were prepared in a sterile fashion and positioned for surgery. A craniolateral approach to the ulna was used, and a longitudinal skin incision was made, ending $4 \mathrm{~cm}$ proximal of the ulnar styloid process. The periosteum was preserved, using a $3-\mathrm{cm}$ longitudinal incision and careful periosteal elevation. A $20-\mathrm{mm}$ bone segment was removed $4 \mathrm{~cm}$ proximal of the ulnar styloid process using an oscillating saw and ample lavage. In this way a critical-sized bone defect, or a defect that will not heal spontaneously, was created. ${ }^{7}$

As canine and porcine $\mathrm{GH}$ are identical at the protein level, recombinant porcine GH provided by Dr. A.F. Parlow of the National Hormone and Pituitary Program (NHPP, Torrance, CA), was used in this study. ${ }^{1}$ Growth hormone was dissolved in $0.03 \mathrm{~mol} / \mathrm{L}$ sodium bicarbonate in $0.15 \mathrm{~mol} / \mathrm{L} \mathrm{NaCl}$, and after adjusting the $\mathrm{pH}$ to 9.5 , the sterile solution was diluted with 0.15 $\mathrm{mol} / \mathrm{L} \mathrm{NaCl}$ to the desired concentration of $30 \mathrm{mg} / \mathrm{mL}$. Four 2ML4 Alzet ${ }^{\circledR}$ osmotic pumps (Alzet ${ }^{\circledR}$ Osmotic pumps, Alza Corporation, Palo Alto, CA) capable of continuous drug delivery for 28 days were filled with $2 \mathrm{~mL}$ rpGH solution and four pumps were filled with the vehicle of the solution (ie, $0.03 \mathrm{~mol} / \mathrm{L}$ sodium bicarbonate in $0.15 \mathrm{~mol} / \mathrm{L} \mathrm{NaCl}$, adjusted to $\mathrm{pH} 9.5$ ). With this GH solution, the pumps delivered $1.8 \mathrm{mg} \mathrm{GH}$ per day for 4 weeks. The pumps were mounted with a $4-\mathrm{cm}$ long Teflon catheter and implanted subcutaneous distally from the critical-sized bone defect, on the right side only. The tip of the catheter was placed in the critical-sized bone defect. The periosteal cylinder was closed with absorbable suture material, while fixing the catheter to the periosteum. In this way a concentration gradient was established, with the greatest amount of GH in the rightsided defect. ${ }^{18,39}$ Closure of the subcutaneous tissues and skin was in a routine fashion. A protective bandage was applied for 3 days. The dogs received analgesics (buprenorphine, 4 times per day, $10 \mu \mathrm{g} / \mathrm{kg}$ body weight subcutaneously) for 3 days postoperatively. Full loading of the legs was permitted immediately after surgery. En bloc biopsies, incorporating a 4-cm segment of the right and left ulnas, including the critical-sized defect, were harvested with the dogs under general anesthesia at 6 weeks. These 16 biopsy specimens were split longitudinally; $1 / 2$ were processed for total RNA isolation, whereas the other $1 / 2$ were fixed in $70 \%$ alcohol for histomorphometric analysis. The dogs were not euthanized, but nursed until completely recovered from surgery. Before the study, new owners were found to adopt the dogs as pets. After recovery, all dogs were united with their owners. Throughout the entire study, the dogs were fed a standard commercial dog food twice a day and water was available ad libitum.

Standardized mediolateral radiographs of the right and left antebrachiums were obtained before surgery, immediately after surgery, and once every 2 weeks thereafter. The radiographs included a ruler and an aluminum step-wedge, consisting of 10, 2-mm thick aluminum slabs mounted in an overlapping manner. Early bone formation and bridging of the critical-sized bone defects were assessed visually, and bone formation was quantified using a densitometric image analysis system. Radiographs were recorded with a Sony black and white CCD camera (Sony Corporation, Tokyo, Japan), Type XC-77CE, and digitized for image analysis (frame size, $752 \times 574$ pixels; 256 grey levels) with a PC-based system equipped with the KS400 version 3.0 software (Carl Zeiss Vision, Oberkochen, Germany). A program was developed in KS400 to quantify the amount of regenerated bone. Each radiograph was calibrated geometrically and densitometrically, using the image of the ruler and the aluminum step-wedge. The densitometric calibration was performed by measuring the mean optical density of a square area of $50 \times 50$ pixels in six steps of the aluminum step-wedge $(0,2,4,6,8$, and $10 \mathrm{~mm}$ ). The measurements were done in a median-filtered image to reduce the influence of the photographic grains in the film. The optical density values are a polygonal fit with the aluminum values to produce a transformation table, which enables expression of the amount of newly formed bone in equivalents of cubic millimeters of aluminum. The region of interest (ROI) included 
the critical-sized bone defect and all new bone formation within $10 \mathrm{~mm}$ proximal and distal of the defect. The ROI was delineated on the digitalized mediolateral images, and densitometric analyses for bone area and bone amount were performed. Densitometric image analysis was performed using the 4-week and 6-week radiographs, as the 2 -week data only showed limited mineralization of the newly formed bone.

The segmental bone biopsy specimens were fixed in $70 \%$ ethanol. After dehydration using increasing concentrations of up to $100 \%$ ethanol, the bone biopsy specimens were embedded in methylmethacrylate, which was allowed to polymerize (polymethylmethacrylate [PMMA]). Longitudinal sections of the PMMA-embedded bone specimens were made using a Leica SP1600 microtome (Leica Microsystems Nussloch GmbH, Nussloch, Germany). The PMMA-embedded bone was mounted on the microtome, the surface was corroded with $1 \%$ hydrochloric acid in ethanol, and stained with a $1 \%$ methylene blue solution and a $0.3 \%$ basic fuchsin solution. Basic fuchsin preferentially binds to bone, whereas fibrous tissue and cartilage is indicated by methylene blue. A cover slip was fixed to the PMMAbone specimen, using light-curing epoxy resin glue. Sections with a thickness of $20 \mu \mathrm{m}$ were sawed. Four longitudinal sections from the center of each critical-sized bone defect including two ulnar cortices on either side of the original defect were selected and used for histomorphometric analysis. To measure the area of trabecular bone in the microscopic sections of the critical-sized defect, a PC-based image analysis system, equipped with the KS400 version 3.0 software package (Carl Zeiss Vision, Oberkochen, Germany) was used. Sections of each defect were scanned macroscopically with a Sony black and white CCD camera type XC-77CE (frame size, $752 \times 574$ pixels; 256 grey levels; Sony Corporation). Before measurement, the system was calibrated geometrically, and shading correction was done. The complete area containing the trabecular bone was outlined manually by one observer (LT), followed by a computerized dynamic discrimination (ie, a threshold procedure accounting for the local background values) of the trabecular differential staining and morphometric properties. With this technique, a distinction was established between trabecular bone opposed to fibrous and cartilaginous tissue. The measured areas were expressed in square millimeters.

The bone biopsy specimens were frozen immediately in liquid nitrogen and stored at $-70^{\circ} \mathrm{C}$ until required for RNA isola- tion. Frozen bone tissue was ground in liquid nitrogen prefrozen cups of a microdismembrator (Micro-Dismembrator U, B. Braun Biotech International GmbH, Melsungen, Germany). One to five hundred milligrams of milled bone tissue was resuspended in Qiagen lysis buffer (Qiagen GmbH, Hilden, Germany) and centrifuged for 10 minutes at $5 \mathrm{~g}$. The supernatant was applied to a Qiagen midi-column (Qiagen GmbH, Hilden, Germany), and total RNA was isolated according to the manufacturer's protocol. After DNase I treatment (DNAfree ${ }^{\mathrm{TM}}$ kit, Ambion, TX), RNA was ethanol precipitated and resuspended in $5 \mu \mathrm{L}$ RNase-free water. As much as $1 \mu \mathrm{g}$ total RNA was used in a $20-\mu \mathrm{L}$ complementary deoxyribonucleic acid (cDNA) synthesis reaction (Reverse Transcription System, Promega Corp, Madison, WI) according to the manufacturer's instructions. The cDNA solution was diluted to an equivalent of $10 \mathrm{ng} \mathrm{RNA} / \mu \mathrm{L}$.

Real-time polymerase chain reaction (PCR), based on the high-affinity double-stranded DNA-binding dye SYBR green I, was performed in triplicate in a spectrofluorometric thermal cycler (iCycler, BioRad, Hercules, CA). Data were collected and analyzed with the provided application software. For each realtime PCR reaction, $5 \mu \mathrm{L}$ of the cDNA dilution was used in a reaction volume of $50 \mu \mathrm{L}$, containing $1 \times \mathrm{PCR}$ buffer, $3 \mathrm{mmol} / \mathrm{L}$ $\mathrm{MgCl}_{2}, 1: 100,000$ dilution of SYBR ${ }^{\circledR}$ green I (BMA, Rockland, $\mathrm{ME}), 10 \mathrm{nmol} / \mathrm{L}$ fluorescein calibration dye (BioRad, Hercules, CA), $200 \mu \mathrm{mol} / \mathrm{L}$ dNTPs, 20 pmol forward primer, $20 \mathrm{pmol}$ reverse primer, and 1.25 units AmpliTaq Gold DNA polymerase (Applied Biosystems, Roche, Branchburg, NJ). Cycling conditions were 5 minutes at $95^{\circ} \mathrm{C}$, followed by 45 cycles of 15 seconds at $95^{\circ} \mathrm{C}, 30$ seconds at $55^{\circ} \mathrm{C}$, and 40 seconds at $72^{\circ} \mathrm{C}$. Primer pairs were designed using PrimerSelect software (DNASTAR, Inc, Madison, WI) (Table 1).

Melt curves (iCycler, BioRad, Hercules) and agarose gel electrophoresis were used to examine each sample for purity, and standard sequencing procedures (ABI PRISM ${ }^{\mathrm{TM}} 310$ Genetic Analyzer, Applied Biosystems, Roche) were used to verify the analytical specificity of the PCR products.

Standard curves constructed by plotting the log of starting amount versus the threshold cycle were generated using serial 10 -fold dilutions of known amounts of PCR products (from a conventional PCR). The amplification efficiency, E $(\%)=$ $\left(10^{(1 /-\mathrm{s})}-1\right) \times 100$ ( $\mathrm{s}=$ slope $)$, of each standard curve was determined and seemed to be greater than $90 \%$ over a large dynamic range (6-8 orders of magnitude). Serial dilutions of

TABLE 1. Primer Pairs Used in PCR Amplification

\begin{tabular}{|c|c|c|c|}
\hline Gene & Primer $\left(5^{\prime}-3^{\prime}\right)$ & Exon & $\begin{array}{l}\text { Amplicon } \\
\text { Length (bp) }\end{array}$ \\
\hline \multirow[t]{2}{*}{$\beta$-actin } & F: TGGCACCACACCTTCTACAACGAG & 3 & \multirow[t]{2}{*}{180} \\
\hline & R: AGAGGCATACAGGGACAGGACAGC & 4 & \\
\hline \multirow[t]{2}{*}{ |GF-| } & F: ATGTCCTCCTCGCATCTCTT & 3 & \multirow[t]{2}{*}{355} \\
\hline & R: TCCCTCTACTTGCGTTCTTC & 5 & \\
\hline \multirow[t]{2}{*}{ |GF-II } & F: CGCAGCCGTGGCATCGTTGAGGAG & 5 & \multirow[t]{2}{*}{200} \\
\hline & R: CTGCGCAGGCGCTGGGTGGACT & 6 & \\
\hline \multirow[t]{2}{*}{$\mathrm{GH}$ receptor } & F: ACCCATCGGCCTCAACTG & 6 & \multirow[t]{2}{*}{175} \\
\hline & R: AGGGTCCATCATTTTCCACTG & 6,7 & \\
\hline
\end{tabular}


cDNA also were tested, resulting in similar E values over three to four orders of magnitude.

For each experimental sample, the amount of target (IGF-I, IGF-II, and GH receptor) and $\beta$-actin as endogenous reference was determined from the appropriate standard curve. To confirm that $\beta$-actin levels were not influenced by the experimental manipulation and to additionally rule out interference of $\beta$-actin pseudogenes, $\beta$-actin, using a primer pair that distinguishes cDNA from pseudogene DNA, was tested as an internal standard. The amount of target was divided by the amount of endogenous reference to obtain a normalized target value.

During the week before surgery, two jugular vein blood samples were collected with a 1-hour interval in ice-chilled ethylenediaminetetraacetic acid (EDTA) tubes and kept on ice before centrifugation for 15 minutes at $3.000 \mathrm{rpm}$ and $4^{\circ} \mathrm{C}$ within 60 minutes after collection. Plasma samples were stored at $-20^{\circ}$ $\mathrm{C}$ until analysis of GH, IGF-I, IGF-II, IGFBP-4, and IGFBP-6. During the 6-week study, two blood samples, with a 1-hour interval, were collected once a week and processed accordingly. To rule out diurnal variations, all blood samples were taken at the same time of the day (ie, 0800 and 0900 hours).

Plasma GH concentrations were measured in a homologous radioimmunoassay as previously described. ${ }^{13}$ Total plasma IGF-I and IGF-II concentrations were measured after acidethanol extraction to remove interfering IGFBPs. ${ }^{14}$ In addition, the absence of interfering IGFBPs in the plasma extracts was investigated. ${ }^{36}$ Insulin-like growth factor-I concentrations were measured in a heterologous radioimmunoassay validated for the dog. ${ }^{32}$ Insulin-like growth factor-I antiserum (UBK 487) was the gift of Doctors Underwood and Van Wyk from the University of North Carolina, via the hormone distribution program of The National Institute of Diabetes and Digestive and Kidney Diseases (NIDDK). Insulin-like growth factor-II concentrations were determined with a heterologous radioimmunoassay validated for the dog, using monoclonal antibodies against rat IGF-II (Amano Enzyme USA Co, Lombard, IL), as described previously. ${ }^{14}$

Plasma IGFBP-4 and IGFBP-6 concentrations were determined by specific heterologous radioimmunoassays using polyclonal antiserum WKZ8209 and WKZ6278, respectively. ${ }^{41,42}$

All statistical analyses were performed using the SPSS 10.1 statistical package (SPSS Inc, Chicago, IL). Levene's statistic was used to test homogeneity of variance between groups. The bone area and bone amount in the densitometric image analysis and the histomorphometric data were evaluated using a Student's $t$ test and a paired samples $t$ test. The gene expression data were evaluated using a Student's t test for statistical analysis of the log-transformed normalized target values. The GH, IGF-I, IGFII, IGFBP-4, and IGFBP-6 data were evaluated using a general linear model (GLM) for repeated measures, with the preoperative levels of Week 0 as a covariant, and a paired-samples t test. Differences were considered significant when $\mathrm{p}<0.05$.

\section{RESULTS}

All dogs had the surgical procedures without complications, and soft tissue wound healing was uneventful. The dogs were fully loading both front legs the day after surgery. After 2 weeks, all dogs showed normal locomotion without signs of lameness.

Growth hormone treatment induced bone healing in the critical-sized defects. New bone formation was visible radiographically in the defects as soon as 2 weeks after surgery in the GH-treated group and the controls. Bone formation started adjacent to the proximal and distal osteotomy sites. In the $\mathrm{GH}$ group, bone formation progressed, and at 6 weeks, three of the dogs showed advanced bilateral bridging of the bone defects, whereas one dog showed extensive new bone formation, but without complete bridging of the right-sided and left-sided defects (Fig 1A). In the control group, dogs showed very little progression of new bone formation and no bridging of defects (Fig 1B). Densitometric image analysis showed an increased bone amount $(\mathrm{p}=0.03$ and $\mathrm{p}=0.01)$ in the GH group at 4 and 6 weeks after surgery. The bone area was increased $(\mathrm{p}=0.01)$ at 6 weeks, but not at 4 weeks $(\mathrm{p}=0.05)$ (Table 2). In the $\mathrm{GH}$ group, bone amount and bone area increased $(\mathrm{p}=0.02$ and $\mathrm{p}=0.002)$ between Week 4 and Week 6. In the histologic sections of the GH-treated dogs, bridging of the defects with trabecular bone was seen (Fig $2 \mathrm{~A})$. The bone defects in the controls showed very little new bone formation, and the defects were filled mainly with fibrous tissue (Fig 2B). In the GH-treated bone defects, the amount of trabecular bone was greater $(\mathrm{p}=$ $0.008)$ than in the controls with $70.9 \pm 15.3 \mathrm{~mm}^{2}$ and $22.4 \pm 4.0 \mathrm{~mm}^{2}$, respectively.

Local infusion of $\mathrm{GH}$ directly into the defects did not additionally enhance bone formation in the $\mathrm{GH}$ group. The densitometric image analysis and histomorphometric analysis showed similar bone healing between the contralateral bone defects.

Six weeks after creation of the bone defects, the expression level of IGF-I in the bone regenerate was lower $(\mathrm{p}=0.03)$ in the GH group than in the controls with 2.9 \pm 0.6 (mean $\pm \mathrm{SEM}$ ) and $7.3 \pm 1.9$, respectively. No increase was seen for the expression levels of IGF-II in the GH-treated animals compared with the controls, with $5.3 \pm$ 1.1 and $2.5 \pm 0.7$, although the trend was greater for expression of IGF-II. The expression level of $\mathrm{GH}$ receptor was similar in both groups with $4.4 \pm 0.8$ and $4.4 \pm 0.7$, respectively. In the $\mathrm{GH}$ group, the expression levels of IGF-I, IGF-II, and GH receptor in the bone regenerate of the right and left defects were similar in magnitude.

Treatment with recombinant porcine $\mathrm{GH}$ at this dosage did not result in an increase of $\mathrm{GH}$ plasma concentrations (Fig 3A). The IGF-I and IGF-II plasma concentrations increased $(\mathrm{p}=0.01$ and $\mathrm{p}=0.01)$ during $\mathrm{GH}$ treatment and were greater $(\mathrm{p}=0.02$ and $\mathrm{p}=0.008)$ than in the control group (Fig 3B-C). In the GH-treated group, IGF-I plasma concentrations peaked at 4 weeks $(p=0.01)$ to 

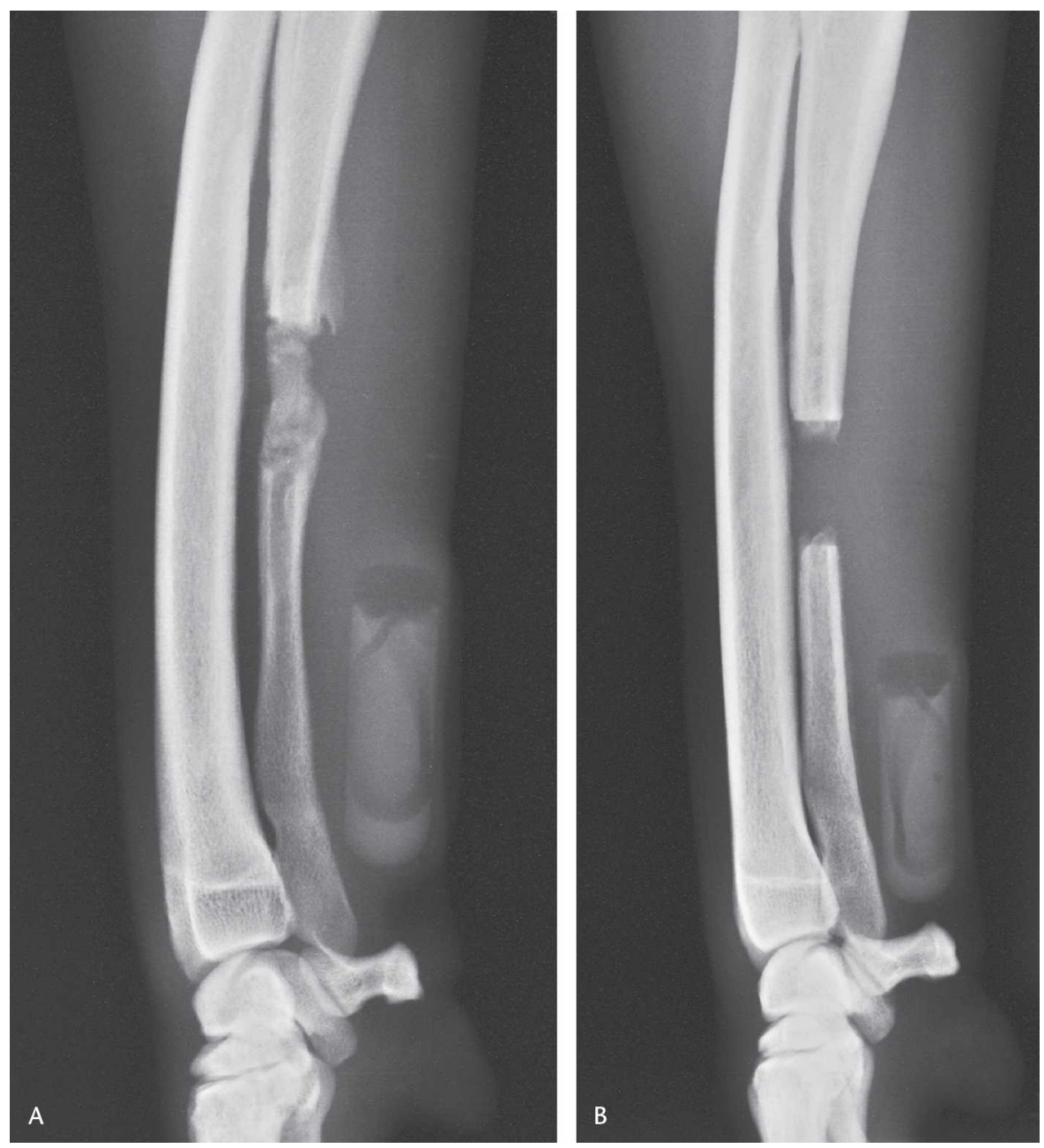

Fig 1A-B. (A) A radiograph was taken of the critical-sized bone defect in the ulna after continuous infusion with $\mathrm{GH}$. The osmotic micropump is located distal to the bone defect. Growth hormone treatment stimulated bone healing with extensive new bone formation and bridging of the defect. (B) A radiograph was taken of the critical-sized bone defect in the ulna after continuous infusion with vehicle solution in the control group. The osmotic micropump is located distal to the defect. The defect shows minimal new bone formation.

rapidly return to pretreatment levels after the $\mathrm{GH}$ infusion had stopped. In contrast, IGF-II levels continued to be greater $(\mathrm{p}=0.008)$ than in the control group for the remainder of the study. In the control group, IGF-II ( $\mathrm{p}=$ $0.02)$ and to a lesser extent IGF-I $(\mathrm{p}=0.03)$ plasma concentrations tended to be lower than the preoperative levels. Plasma IGFBP-4 and IGFBP-6 concentrations were not decreased in the $\mathrm{GH}$-treated dogs, but were similar to the controls. Increases ( $p=0.02$ ) in IGFBP-6 levels were seen in the controls at Weeks 1 and 2 (Fig 3D).

\section{DISCUSSION}

Dealing with bone deficits is a major concern in orthopaedic surgery. We hypothesized that continuous GH administration induces bone healing in a critical-sized bone defect model. In addition, we speculated that local administration of $\mathrm{GH}$ was most effective in enhancing bone healing. The effect of $\mathrm{GH}$ was expected to be mediated twofold, first by stimulating the expression of IGF-I, IGFII, and $\mathrm{GH}$ receptor in the bone regenerate of the original defects and second, by altering circulating plasma concentrations of IGF-I, IGF-II, IGFBP-4 and IGFBP-6. Results

TABLE 2. Densitometric Image Analysis of Bilateral Ulnar Critical-sized Bone Defects

\begin{tabular}{cccr}
\hline $\begin{array}{c}\text { Densitometric } \\
\text { Image Analysis }\end{array}$ & Week & rpGH & Control \\
\hline $\begin{array}{c}\text { Bone area }\left(\mathrm{mm}^{2}\right) \\
\text { Bone amount } \\
\left(\mathrm{mm}^{3} \mathrm{Al} \times 10^{3}\right)\end{array}$ & 4 & $163.8 \pm 27.7$ & $86.5 \pm 23.9$ \\
$\begin{array}{c}\text { Bone area }\left(\mathrm{mm}^{2}\right) \\
\text { Bone amount } \\
\left(\mathrm{mm}^{3} \mathrm{Al} \times 10^{3}\right)\end{array}$ & 6 & $117.9 \pm 20.8^{*}$ & $57.6 \pm 16.4$ \\
\hline
\end{tabular}

Data are presented as mean $\pm \mathrm{SEM}$; bone amount is presented as equivalents of aluminium (Al) in $\mathrm{mm}^{3} \times 10^{3}$; *Significant difference in comparison with the control group $(p<0.05)$; †Significant increase in comparison with Week 4 ( $p<$ 0.01) 


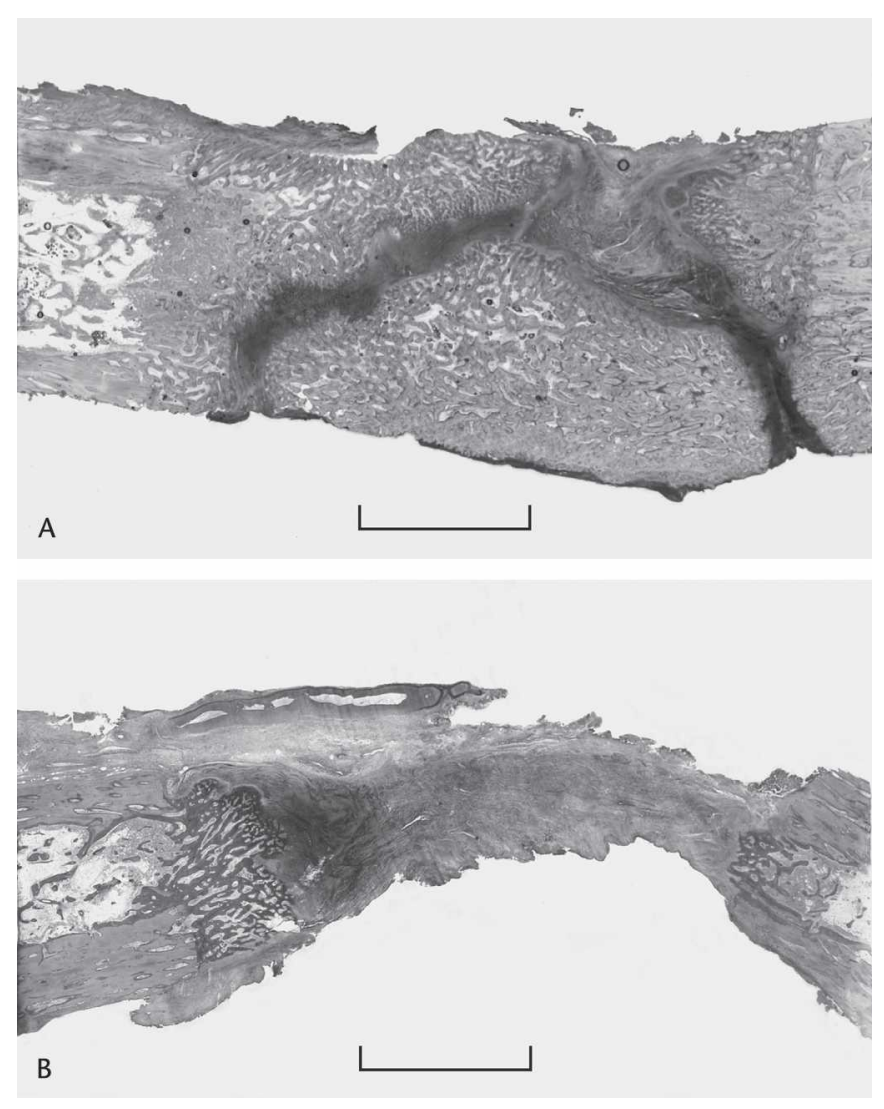

Fig 2A-B. (A) A microscopic section of the critical-sized bone defect, obtained after continuous infusion with growth hormone, shows the bone regenerate in the original defect. Growth hormone treatment has induced bone healing, filling the defect almost completely with trabecular bone. The bar represents $5 \mathrm{~mm}$. (B) A microscopic section of the criticalsized bone defect, obtained after continuous infusion with vehicle solution in the control group, shows the defect is filled with fibrous tissue and there is only minimal formation of trabecular bone. The bar represents $5 \mathrm{~mm}$.

of our study indicate that continuous infusion with $\mathrm{GH}$ stimulates bone formation and bone healing in a criticalsized bone defect. The model reproduced a nonunion in all nontreated dogs. ${ }^{7}$ Local delivery of GH did not additionally enhance bone healing. Growth hormone treatment did not increase the expression of IGF-I, IGF-II, and GH receptor in the bone regenerate at 6 weeks after creation of the defect. Increased circulating plasma concentrations of IGF-I and IGF-II most likely induced bone formation during $\mathrm{GH}$ treatment.

The local continuous administration of $\mathrm{GH}$ into the right-sided bone defect using an osmotic pump and a catheter was limited by redistribution of GH to the circulation. Nevertheless, our interest was to determine whether this route of infusion, which is feasible in a clinical setting, could effectively enhance local bone regeneration. An- other approach could be delivery of GH with a slowreleasing carrier, but this route of administration was not readily available and technically was more demanding.

Exploring gene-expression levels, including IGF-I, IGF-II, and GH receptor, is limited by the fact that mRNA levels can change in a short time. Determining transcription levels at more than one time can overcome this problem, but requires substantially more experimental animals, as biopsies of the bone regenerate will interfere with normal bone healing. Therefore, we decided to limit our study to the expression levels during the consolidation phase of the bone regenerate at 6 weeks after creation of the defects. Another restriction is that we only determined the expression of IGF-I, IGF-II, and GH receptor. Pursuing additional bone growth factors, including bone morphogenetic proteins, transforming growth factor- $\beta$, fibroblast growth factors, vascular endothelial growth factor, platelet-derived growth factor, and stimulatory IGF binding proteins is essential to elucidate the interactions between bone growth factors. ${ }^{5,7,18,20,29,43}$ Simultaneous determination of these factors is hampered by the amount of bone needed for mRNA isolation.

Although stimulation of bone healing with GH has been reported, our study was the first to show the effectiveness of $\mathrm{GH}$ on bone regeneration in a critical-sized bone defect. $^{2,3,9,21,33,34,44}$ Hypophyseal GH represents the major constituent of GH in the circulation, but GH also is expressed in numerous other tissues, including bone. ${ }^{6,28} \mathrm{Ex}-$ pression of GH in healing bone has not been reported, and local production of $\mathrm{GH}$ in the bone regenerate is not expected to play an important role.

A direct effect of $\mathrm{GH}$ on bone healing was seen in a rat model. ${ }^{21}$ This direct effect of GH should involve the GH receptor, and although the role of the GH receptor in bone growth is slowly being elucidated, little is known regarding its part in osteogenesis in the mature animal. ${ }^{27,28}$ The presence and hormonal control of GH receptor were reported in germinal and proliferative cells in the growth plate and in maturing chondrocytes. ${ }^{17}$ In our study, no additional direct effect of local GH application was seen. As GH receptor expression levels were equal in $\mathrm{GH}$ treated dogs and controls, there was no indication that modulation of $\mathrm{GH}$ receptor expression was responsible for enhanced bone formation. Nevertheless, GH receptor expression was consistent with the concept of a potential direct effect of GH on bone healing. We found that this direct effect of GH was less important during bone regeneration than the indirect effects of GH infusion. Growth hormone plasma concentrations were not greater in the recombinant porcine GH-treated dogs, most likely because of the pulsatile release of endogenous $\mathrm{GH}^{14}$

The GH-induced increases in IGF-I and IGF-II plasma concentrations in the dogs in our study were consistent 


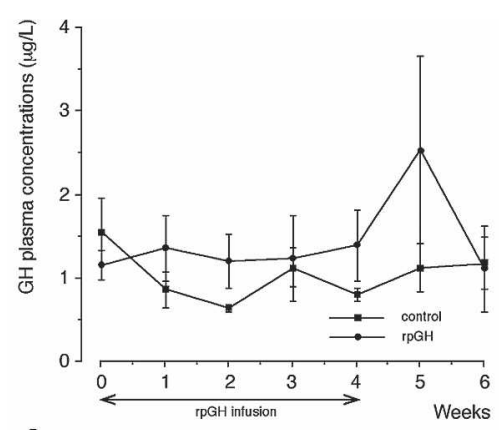

A

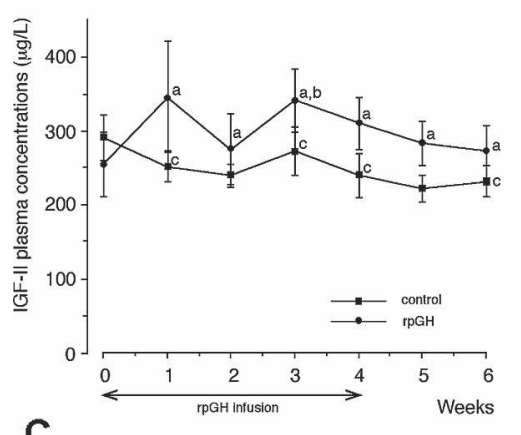

C

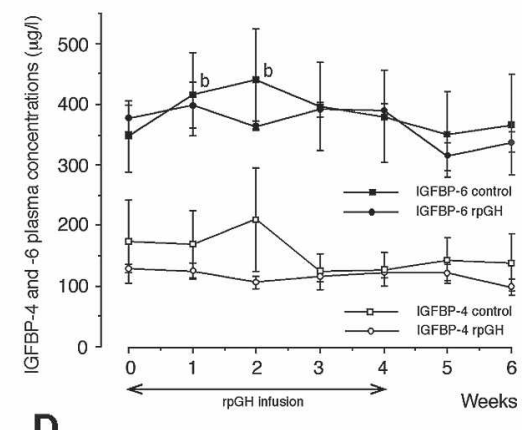

Fig 3A-D. Plasma concentrations are shown for (A) growth hormone (GH), (B) IGF-I, (C) IGF-II, and (D) IGFBP-4, and IGFBP-6 in a canine critical-sized bone defect model during continuous infusion with recombinant porcine $\mathrm{GH}$ (rpGH). Data are presented as means \pm SEM, before surgery $(0)$ and in weeks after surgery. Growth hormone treatment increased IGF-I and IGF-II plasma concentrations, but did not decrease the inhibitory binding proteins IGFBP-4 and IGFBP-6. "Significant increase in the GH group in comparison with the controls $(p<0.05)$; ${ }^{\dagger}$ Significant increase in comparison with the level before surgery $(p<$ $0.05)$; 'Significant decrease in comparison with the level before surgery $(p<0.05)$ with the finding of increased circulating IGF-I and IGF-II concentrations during $\mathrm{GH}$ treatment in postmenopausal women. ${ }^{25}$ The stimulation of bone healing through GHinduced IGF-I was shown in models. ${ }^{3,9,21,33,34}$ In a mouse model, the major part of circulating IGF-I was liverderived. ${ }^{35}$ In our study, we used continuous GH infusion because this was most effective in increasing IGF-I plasma concentrations in humans. ${ }^{24}$ In addition to liver-derived IGF-I production, IGF-I also is known to be expressed locally during bone healing. ${ }^{5,11,19}$ Local IGF-I application stimulated bone healing in a rat model. ${ }^{34}$ In our study, IGF-I expression levels were lower during the consolidation phase of the GH-stimulated bone regenerate. In theory, this suggests that local IGF-I production was not responsible for progression of bone healing at this stage. The decreased expression of IGF-I also can be related to the temporal aspect of ceasing GH infusion after 4 weeks, at which time IGF-I plasma concentrations peaked, and in determining local IGF-I expression after 6 weeks. Bone accretion progressed despite the fact that IGF-I plasma concentrations returned to preoperative levels after cessation of GH infusion. These findings could be consistent with a role of IGF-I during the early stages of callus formation. $^{5}$

Insulin-like growth factor-II is considered to be a major constituent of local and systemic growth factors in bone. ${ }^{4}$ Knowledge regarding the role of IGF-II in bone healing, however, is limited. Insulin-like growth factor-I and IGF-
II were shown to be important for osteoblast survival and apoptosis. ${ }^{23}$ In addition, IGF-I and IGF-II were proposed to modulate osteoblast-osteoclast interactions, which are critical in bone remodeling. ${ }^{22}$ In our study, IGF-II plasma concentrations remained elevated even after cessation of GH infusion. As IGF-II expression did not differ between the GH-treated defects and the controls, we theorize that IGF-II production by skeletal osteoblasts outside the defects is responsible for the enhanced bone regeneration. Elevated IGF-II plasma concentrations could account for the increase in densitometric bone amount and bone area between Weeks 4 and 6 . The increase in bone amount, but not bone area, in the controls could be attributed to mineralization of the small amount of bone formed at the osteotomy sites.

Insulin-like growth factor binding protein-4 and IGFBP-6 are reported to play an important role in modulating IGF actions in bone, mainly by inhibiting osteoblast function. ${ }^{10,26}$ In our study, IGFBP-4 plasma concentrations were comparable with plasma concentrations in humans. ${ }^{41}$ Continuous infusion with rpGH did not result in an increase of IGFBP-4 levels as seen in previous studies during GH replacement therapy in humans. ${ }^{25,38}$ Canine IGFBP-6 plasma concentrations tended to be twice as high as in their human counterparts. ${ }^{42}$ Because IGFBP6 preferentially binds IGF-II, IGFBP-6 could be important in modulating IGF-II actions. ${ }^{37,42,45}$ In our study, IGFBP-4 and IGFBP-6 plasma concentrations were not affected by 
continuous GH infusion and did not seem to play a role during enhanced bone regeneration.

Continuous GH infusion stimulated bone healing in this canine critical-sized bone defect model. Local delivery of $\mathrm{GH}$ did not additionally enhance bone healing. Increased plasma concentrations of IGF-I and IGF-II most likely induced bone regeneration. Growth hormone could play an important role in stimulating bone formation during the surgical treatment of bone defects.

\section{Acknowledgments}

We thank Y. van der Helm of the Orthopaedic Research Laboratory of the Utrecht MedicalCentre, Utrecht University, for support during preparation of bone sections, $\mathrm{M}$. Terlou for technical assistance during densitometric and histomorphometric image analysis, and $\mathrm{H}$. Halsema for the graphic work.

\section{References}

1. Ascacio-Martinez JA, Barrera-Saldana HA. A dog growth hormone cDNA codes for a mature protein identical to pig growth hormone. Gene. 1994;143:277-280.

2. Bail HJ, Kolbeck S, Krummrey G, Schmidmaier G, Haas NP, Raschke MJ. Systemic application of growth hormone for enhancement of secondary and intramembranous fracture healing. Horm Res. 2002;58(suppl 3):39-42.

3. Bail HJ, Kolbeck S, Lindner T, Dahne M, Weiler A, Windhagen HJ, Raun K, Skjaerbaek C, Flyvbjerg A, Orskov H, Haas NP, Raschke MJ. The effect of growth hormone on insulin-like growth factor I and bone metabolism in distraction osteogenesis. Growth Horm IGF Res. 2001;11:314-323.

4. Bautista CM, Mohan S, Baylink DJ. Insulin-like growth factors I and II are present in the skeletal tissues of ten vertebrates. Metabolism. 1990;39:96-100.

5. Bourque WT, Gross M, Hall BK. Expression of four growth factors during fracture repair. Int J Dev Biol. 1993;37:573-579.

6. Conzemius MG, Brown DC, Brabec M, Smith GK, Washabau R, LaFond E, Chakraborty PK. Correlation between longitudinal bone growth, growth hormone, and insulin-like growth factor-I in prepubertal dogs. Am J Vet Res. 1998;59:1608-1612.

7. Cook SD, Baffes GC, Wolfe MW, Sampath TK, Rueger DC. Recombinant human bone morphogenetic protein-7 induces healing in a canine long-bone segmental defect model. Clin Orthop Relat Res. 1994;301:302-312.

8. Drake WM, Carroll PV, Savage MO, Monson JP. Skeletal consequences of discontinuation of growth hormone at final height. $J$ Pediatr Endocrinol Metab. 2002;15(suppl 5):1351-1354.

9. Dubreuil P, Abribat T, Broxup B, Brazeau P. Long-term growth hormone-releasing factor administration on growth hormone, insulin-like growth factor-I concentrations, and bone healing in the Beagle. Can J Vet Res. 1996;60:7-13.

10. Durham SK, Riggs BL, Conover CA. The insulin-like growth factor-binding protein-4 (IGFBP-4)-IGFBP-4 protease system in normal human osteoblast-like cells: regulation by transforming growth factor-beta. J Clin Endocrinol Metab. 1994;79:1752-1758.

11. Edwall D, Prisell PT, Levinovitz A, Jennische E, Norstedt G. Expression of insulin-like growth factor I messenger ribonucleic acid in regenerating bone after fracture: influence of indomethacin. $J$ Bone Miner Res. 1992;7:207-213.

12. Ehrnborg C, Lange KH, Dall R, Christiansen JS, Lundberg PA, Baxter RC, Boroujerdi MA, Bengtsson BA, Healey ML, Pentecost C, Longobardi S, Napoli R, Rosen T. The growth hormone/insulinlike growth factor-I axis hormones and bone markers in elite athletes in response to a maximum exercise test. J Clin Endocrinol Metab. 2003;88:394-401.
13. Eigenmann JE, Eigenmann RY. Radioimmunoassay of canine growth hormone. Acta Endocrinol (Copenh). 1981;98:514-520.

14. Favier RP, Mol JA, Kooistra HS, Rijnberk A. Large body size in the dog is associated with transient GH excess at a young age. $J$ Endocrinol. 2001;170:479-484.

15. Fukuda S, Iida H. Effects of orchidectomy on bone metabolism in beagle dogs. J Vet Med Sci. 2000;62:69-73.

16. Geusens P, Schot LP, Nijs J, Dequeker J. Calcium-deficient diet in ovariectomized dogs limits the effects of 17 beta-estradiol and nandrolone decanoate on bone. J Bone Miner Res. 1991;6:791-797.

17. Gevers EF, van der Eerden BC, Karperien M, Raap AK, Robinson IC, Wit JM. Localization and regulation of the growth hormone receptor and growth hormone-binding protein in the rat growth plate. J Bone Miner Res. 2002;17:1408-1419.

18. Goodman SB, Song Y, Yoo JY, Fox N, Trindade MC, Kajiyama G, Ma T, Regula D, Brown J, Smith RL. Local infusion of FGF-2 enhances bone ingrowth in rabbit chambers in the presence of polyethylene particles. J Biomed Mater Res A. 2003;65:454-461.

19. Hayden JM, Mohan S, Baylink DJ. The insulin-like growth factor system and the coupling of formation to resorption. Bone. 1995;17: 93S-98S.

20. Heckman JD, Boyan BD, Aufdemorte TB, Abbott JT. The use of bone morphogenetic protein in the treatment of non-union in a canine model. J Bone Joint Surg. 1991;73:750-764.

21. Hedner E, Linde A, Nilsson A. Systemically and locally administered growth hormone stimulates bone healing in combination with osteopromotive membranes: an experimental study in rats. $J$ Bone Miner Res. 1996;11:1952-1960.

22. Hill PA, Reynolds JJ, Meikle MC. Osteoblasts mediate insulin-like growth factor-I and -II stimulation of osteoclast formation and function. Endocrinology. 1995;136:124-131.

23. Hill PA, Tumber A, Meikle MC. Multiple extracellular signals promote osteoblast survival and apoptosis. Endocrinology. 1997;138: 3849-3858.

24. Jaffe CA, Turgeon DK, Lown K, Demott-Friberg R, Watkins PB. Growth hormone secretion pattern is an independent regulator of growth hormone actions in humans. Am J Physiol Endocrinol Metab. 2002;283:1008-1015.

25. Kassem M, Brixen K, Mosekilde L, Blum WF, Flyvbjerg A. Effects of growth hormone treatment on serum levels of insulin-like growth factors (IGFs) and IGF binding proteins 1-4 in postmenopausal women. Clin Endocrinol (Oxf). 1998;49:747-756.

26. Kelley KM, Oh Y, Gargosky SE, Gucev Z, Matsumoto T, Hwa V, $\mathrm{Ng}$ L, Simpson DM, Rosenfeld RG. Insulin-like growth factorbinding proteins (IGFBPs) and their regulatory dynamics. Int $J$ Biochem Cell Biol. 1996;28:619-637.

27. Kelly PA, Finidori J, Moulin S, Kedzia C, Binart N. Growth hormone receptor signalling and actions in bone growth. Horm Res. 2001;55(suppl 2):14-17.

28. Kirpensteijn J, Timmermans-Sprang EP, van Garderen E, Rutteman GR, Lantinga-van Leeuwen IS, Mol JA. Growth hormone gene expression in canine normal growth plates and spontaneous osteosarcoma. Mol Cell Endocrinol. 2002;197:179-185.

29. Linkhart TA, Mohan S, Baylink DJ. Growth factors for bone growth and repair: IGF, TGF beta and BMP. Bone. 1996;19:1-12.

30. Mohan S. Insulin-like growth factor binding proteins in bone cell regulation. Growth Regul. 1993;3:67-70.

31. Mohan S, Richman C, Guo R, Amaar Y, Donahue LR, Wergedal J, Baylink DJ. Insulin-like growth factor regulates peak bone mineral density in mice by both growth hormone-dependent and -independent mechanisms. Endocrinology. 2003;144:929-936.

32. Nap RC, Mol JA, Hazewinkel HA. Age-related plasma concentrations of growth hormone $(\mathrm{GH})$ and insulin- like growth factor I(IGF-I) in Great Dane pups fed different dietary levels of protein. Domest Anim Endocrinol. 1993;10:237-247.

33. Raschke MJ, Bail H, Windhagen HJ, Kolbeck SF, Weiler A, Raun K, Kappelgard A, Skiaerbaek C, Haas NP. Recombinant growth hormone accelerates bone regenerate consolidation in distraction osteogenesis. Bone. 1999;24:81-88.

34. Schmidmaier G, Wildemann B, Heeger J, Gabelein T, Flyvbjerg A, 
Bail HJ, Raschke M. Improvement of fracture healing by systemic administration of growth hormone and local application of insulinlike growth factor-1 and transforming growth factor-beta1. Bone. 2002;31:165-172.

35. Sjogren K, Jansson JO, Isaksson OG, Ohlsson C. A model for tissue-specific inducible insulin-like growth factor-I (IGF-I) inactivation to determine the physiological role of liver-derived IGF-I. Endocrine. 2002;19:249-256.

36. Sota de la RL. Simmen FA, Diaz T, Thatcher WW. Insulin-like growth factor system in bovine first-wave dominant and subordinate follicles. Biol Reprod. 1996;55:803-812.

37. Srinivasan N, Edwall D, Linkhart TA, Baylink DJ, Mohan S. Insulin-like growth factor-binding protein-6 produced by human PC-3 prostate cancer cells: isolation, characterization and its biological action. J Endocrinol. 1996;149:297-303.

38. Thoren M, Hilding A, Brismar T, Magnusson P, Degerblad M, Larsson L, Saaf M, Baylink DJ, Mohan S. Serum levels of insulinlike growth factor binding proteins (IGFBP)- 4 and -5 correlate with bone mineral density in growth hormone $(\mathrm{GH})$ - deficient adults and increase with GH replacement therapy. J Bone Miner Res. 1998; 13:891-899.

39. Tiangco DA, Papakonstantinou KC, Mullinax KA, Terzis JK. IGF-I and end-to-side nerve repair: a dose-response study. J Reconstr Microsurg. 2001;17:247-256.

40. Tryfonidou MA, Holl MS, Vastenburg M, Oosterlaken-Dijksterhuis
MA, Birkenhager-Frenkel DH, van den Brom WE, Hazewinkel HA. Hormonal regulation of calcium homeostasis in two breeds of dogs during growth at different rates. J Anim Sci. 2003;81:1568-1580.

41. van Doorn J, Cornelissen AJ, Buul-Offers SC. Plasma levels of insulin-like growth factor binding protein-4 (IGFBP-4) under normal and pathological conditions. Clin Endocrinol (Oxf). 2001;54: 655-664.

42. van Doorn J, Ringeling AM, Shmueli SS, Kuijpers MC, HokkenKoelega AC, Buul-Offers SC, Jansen M. Circulating levels of human insulin-like growth factor binding protein- 6 (IGFBP-6) in health and disease as determined by radioimmunoassay. Clin Endocrinol (Oxf). 1999;50:601-609.

43. Welch RD, Jones AL, Bucholz RW, Reinert CM, Tjia JS, Pierce WA, Wozney JM, Li XJ. Effect of recombinant human bone morphogenetic protein-2 on fracture healing in a goat tibial fracture model. J Bone Miner Res. 1998;13:1483-1490.

44. Wilkens BE, Millis DL, Daniel GB, Munson L, Patel KR, Buonomo FC. Metabolic and histologic effects of recombinant canine somatotropin on bone healing in dogs, using an unstable ostectomy gap model. Am J Vet Res. 1996;57:1395-1401.

45. Yu H, Mistry J, Nicar MJ, Khosravi MJ, Diamandis A, van Doorn J, Juul A. Insulin-like growth factors (IGF-I, free IGF-I and IGF-II) and insulin- like growth factor binding proteins (IGFBP-2, IGFBP3, IGFBP-6, and ALS) in blood circulation. J Clin Lab Anal. 1999; $13: 166-172$. 